\title{
Physical characterization of a watershed through GIS: a study in the Schmidt stream, Brazil
}

\author{
D. R. Reis ${ }^{a}$, R. Plangg ${ }^{a}$, J. G. Tundisi ${ }^{a}$ and D. M. Quevedo ${ }^{a *}$ \\ aPrograma de Pós-graduação em Qualidade Ambiental, Universidade Feevale, \\ RS 239, 2755, Bairro Vila Nova, Novo Hamburgo, RS, Brazil \\ *e-mail: danielamq@feevale.br
}

Received: January 17, 2015 - Accepted: May 20, 2015 - Distributed: November 30, 2015

(With 10 figures)

\begin{abstract}
Remote sensing and geoprocessing are essential tools for obtaining and maintaining records of human actions on space over the course of time; these tools offer the basis for diagnoses of land use, environmental interference and local development. The Schmidt stream watershed, located in the Sinos River basin, in southern Brazil, has an environmental situation similar to that of the majority of small streams draining rural and urban areas in southern Brazil: agricultural and urbanization practices do not recognize the riparian area and there is removal of original vegetation, disregarding the suitability of land use; removal of wetlands; intensive water use for various activities; and lack of control and monitoring in the discharge of wastewater, among other factors, deteriorate the quality of this important environment.This article aims to achieve a physical characterization of the Schmidt stream watershed (Sinos river basin) identifying elements such as land use and occupation, soil science, geology, climatology, extent and location of watershed, among others, so as to serve as the basis for a tool that helps in the integrated environmental management of watersheds. By applying geographic information system - GIS to the process of obtaining maps of land use and occupation, pedologicaland geological, and using climatological data from the Campo Bom meteorological station, field visit, review of literature and journals, and publicly available data, the physical characterization of the Schmidt stream watershed was performed, with a view to the integrated environmental management of this watershed. Out of the total area of the Schmidt stream watershed $\left(23.92 \mathrm{~km}^{2}\right)$, in terms of geology, it was observed that $23.7 \%$ consist of colluvial deposits, $22.6 \%$ consist of grass facies, and $53.7 \%$ consist of Botucatu formation. Major soil types of the watershed: $97.4 \%$ Argisols and only $2.6 \%$ Planosols. Land use and occupation is characterized by wetland (0.5\%), Native Forest (12.83\%), Native Forest + Rural Anthropic + Secondary Vegetation + Forestry (43.81\%), Urban Anthropic/Urban Area (39.85\%), and also Urban Anthropic/Expansion areas (3.01\%). Mean annual rainfall is $1337 \mathrm{~mm}$, maximum temperatures range from $10.5^{\circ} \mathrm{C}$ to $41.6^{\circ} \mathrm{C}$ and minimum temperatures range from $-1.80^{\circ} \mathrm{C}$ and $26^{\circ} \mathrm{C}$, weak winds, occasionally over $5 \mathrm{~m} / \mathrm{s}$. Conducting an environmental assessment in this watershed is essential for environmental and land management. However, these assessments are not conducted in all watersheds and, when they are, their frequency is not sufficiency to allow for continuous monitoring, in order to model and predict scenarios, with a view to adopt medium and long-term measures for environmental protection.
\end{abstract}

Keywords: land use mapping, environmental management, geographic information systems, micro basin.

\section{Caracterização física de microbacia hidrográfica através de SIG como ferramenta de apoio a gestão: um estudo no Arroio Schmidt - RS}

\begin{abstract}
Resumo
O sensoriamento remoto e geoprocessamento de imagens se constituem em ferramentas fundamentais para a obtenção e manutenção de registros das ações humanas no espaço ao longo do tempo subsidiando diagnósticos no uso do solo, na interferência ambiental e no desenvolvimento local. A microbacia do Arroio Schmidt, localizada na bacia do Rio dos Sinos, no Rio Grande do Sul, apresenta situação ambiental semelhante a da maioria dos pequenos cursos d'agua que drenam áreas rurais e urbanas no sul do Brasil: práticas agrícolas e urbanização que não reconhecem a área ciliar com a remoção da cobertura vegetal original desrespeitando a aptidão do uso dos solos, remoção de áreas úmidas, uso intenso da água para diversas atividades e falta de controle e monitoramento no lançamento de efluentes entre outros, deterioram a qualidade deste importante ambiente. O objetivo deste trabalho é a caracterização física da Microbacia do Arroio Schmidt (Bacia do Rio dos Sinos) identificando elementos como uso e ocupação do solo, pedologia, geologia, climatologia, extensão e localização da Microbacia entre outros, a fim de instrumentalizar uma ferramenta auxiliar de gestão ambiental integrada de bacias hidrográficas. Através da aplicação do geoprocessamento no processo de obtenção dos mapas de uso e ocupação do solo, pedológico e geológico e uso de dados climatológicos da estação climatológica
\end{abstract}


de Campo Bom-RS, visita a campo, revisão bibliográfica e de periódicos, dados públicos disponíveis, foi realizada a caracterização física da microbacia hidrográfica do Arroio Schmidt, visando a gestão ambiental integrada desta microbacia. Da área total da microbacia hidrográfica do Arroio Schmidt $\left(23,92 \mathrm{~km}^{2}\right)$ observou-se quanto à geologia que 23,7\% são Colúvios, Fácies Gramado 22,6\% e Formação Botucatu 53,7\%. Principais tipos de solos da microbacia: Argissolos $97,4 \%$ e os Planossolos que ocupam apenas 2,6\%. O uso e ocupação do solo é caracterizado por área úmida (0,5\%), Mata Nativa (12,83\%), Mata Nativa + Antrópico Rural + Vegetação Secundária + Silvicultura (43,81\%), Antrópico Urbano/Área Urbana (39,85\%) e ainda Antrópico Urbano/Áreas de expansão (3,01\%). Precipitação média anual de $1337 \mathrm{~mm}$, temperaturas máximas entre $10,5^{\circ} \mathrm{C}$ e $41,6^{\circ} \mathrm{C}$ e as mínimas entre $-1,8^{\circ} \mathrm{C}$ e $26^{\circ} \mathrm{C}$, Ventos fracos, eventualmente passam de $5 \mathrm{~m} / \mathrm{s}$. A realização da avaliação ambiental nesta microbacia é fundamental na gestão ambiental e territorial. No entanto, estas avaliações não ocorrem em todas as microbacias e, quando ocorrem, não apresentam a frequência adequada para permitir o monitoramento contínuo a fim de modelar e prever cenários objetivando a adoção de medidas de médio e longo prazo para a proteção ambiental.

Palavras-chave: mapeamento do uso do solo, gestão ambiental, sistemas de informação geográfica, microbacia hidrográfica.

\section{Introduction}

The way the relationship between humans and the environment has been taking place has caused a succession and variety of environmental problems, causing rapid degradation, such as: soil and water contamination, air pollution, loss of soil productivity, erosion, which, in turn, causes overflowing, landslides, siltation of rivers, floods, and desertification, among many others. According to Tundisi (2003), anthropogenic actions that do not consider the dynamics of aquatic ecosystems affect the hydrological cycle, thus reducing the infiltration capacity of water in the the soil, changing the regime of rivers and precluding the recharging ability of reserves. Therefore, knowing the environment is essential for effectively planning ways to appropriate these territories and the activities that take place on them, whether for environmental recovery or to foster the proper use of spaces in accordance with their capacities in new activities brought on by human activities. Thus, the necessary first step in the organization and planning process for the area is diagnosis and evaluation.

The use of GIS in the definition, assessment, mapping, and analysis of natural resources and human activities serves as the basis for the instruments of public policies related to the environment. Parameters and processes integrated with other areas of science allow managers to make decisions based on data, thus minimizing costs, time and risks. According to Donha et al. (2006), GIS technology has been used by various sectors in environmental approaches as an environmental planning tool, with advantages that include integrated assessment of a large number of variables in a simplified manner, allowing for rapid generation of intermediate and final information, as well as inclusion of variables not previously considered, once it allows for new interactions and updates at any time.

The ANINQAS proposal - Monitoring of Watersheds in Urban and Rural areas - Integrated Analysis of Water Quality and Socioeconomic Aspects (management of water quality and quantity - BAISINOS) submitted to public Call MCT/FINEP CT-HIDRO 01/2010 is characterized by the proposition of a network of research partnerships between UFMA - Universidade Federal do Maranhão,
UTFPR - Universidade Federal Tecnológica do Paraná, UEM - Universidade Estadual de Maringá e Universidade FEEVALE, under the coordination of FEEVALE/IIE. This proposal consists of several subprojects, and the subproject 5 - Water quality and quantity management of four urban and rural watersheds representative of the Sinos River Valley - BAISINOS motivated the choice of Schmidt stream for this research activity, especially because it is one of the watersheds targeted by this project. Still, the fact that this watershed is located in a region of intense urbanization with strong industrial development, characterized in several reports, mainly from the National Water Agency - ANA as being problematic both in terms of qualitative and quantitative supply of water.

The diagnosis of the environmental conditions of a particular area requires knowledge of environmental problems resulting from the occupation and use of the soil. This information can be obtained by studying the strategies for the use of land, water and biodiversity applied to defined geographical areas.

According to Dalmolin and Pedron (2004), the diversity of the changes in soils from urban areas makes it difficult to classify the Brazilian System of Soil Classification - SiBCS (EMBRAPA, 1999), which so far does not include a term for anthropic or urban soil. The variety of effects in urban soils, resulting from human activities such as probing and dredging; foundations for construction sites, and all operations of moving lands for the deployment of infrastructure systems, both underground (sewerage, water supply, electric power, telecommunications and gas distribution), and above ground (urban drainage), as well as deployment of roads, hamper the establishment of an appropriate classification system.

As for the terminology adopted as reference for the micro basin, or watershed under study, a few conceptual differences have been observed. Once micro basins are drainage areas for tributaries of the main watercourse, namely river basins, different authors use different concepts. Among these, the classification of river basins into large and small, under the Hydrology perspective, is regarded as considering the effects of the dominant factors in the 
generation of runoff, where watersheds are highly sensitive to both high-intensity rainfall and to land use (vegetation cover). This characteristic contributes to the distinction, definition and spatial delineation of watersheds and river basins, and its understanding is critical to structuring environmental monitoring programs, thus, allowing for the establishment of a spatial suitability of watersheds and river basins (Calijuri and Bubel, 2006).

Another important concept attributed to watersheds is the ecological aspect, which, according to Leonardo (2003), considers the smallest unit of the ecosystem, where the delicate interdependence between biotic and abiotic factors can be observed, and disruptions may jeopardize the dynamics of its functioning. This concept aims to identify and monitor environmental impacts in a guided manner.

Also, Guerra (1999), states that the area must be large enough to allow the interrelationships between the various elements of the characteristic environmental framework to be identified, and small enough to be compatible with the available resources, in order to respond positively to the objectives.

This article aims to achieve a physical characterization of the Schmidt stream micro basin (Sinos river basin) identifying elements such as land use and occupation, soil science, geology, climatology, extent and location of watershed, among others, so as to serve as the basis for a tool that helps in the integrated environmental management of watersheds.

\section{Material and Methods}

For this research, GIS resources were used, with vectorized data that helped create themed maps of the area under study. The data collecting, editing and analysis stages are important moments for the processing of the results in this article, which aims to characterize the Schmidt watershed area with a view to the integrated environmental management of this watershed.

\subsection{Study site}

The Schmidt stream watershed is located primarily in the municipality of Campo Bom, in the Sinos River Valley, state of Rio Grande do Sul, Brazil, and is a part of the Sinos river basin, which is, in turn, part of the Guaiba river basin. The municipality of Campo Bom has an area of $61.4 \mathrm{~km}^{2}$ and it is surrounded by the municipalities of Dois Irmãos and Sapiranga (north); Novo Hamburgo (south); Sapiranga (east) and, once again, Novo Hamburgo (west).

According to the IBGE census (IBGE, 2010a), the rural population of Campo Bom was 2,736 people, and the urban population was 57,345 .

The geographical area of the municipality of Campo Bom, where Schmidt stream is located, has a mean elevation of $20 \mathrm{~m}$ above sea level and a minimum of $3.8 \mathrm{~m}$ above the level of the Sinos River, with a latitude of $29^{\circ} 40^{\prime} 54^{\prime \prime}$ - South and a longitude of $51^{\circ} 03$ ' $25^{\prime \prime}$ - West. The climate is mesothermal subtropical (IBGE, 2010b).

According to IBGE (2010c), the natural biome is Atlantic Forest and Pampa, and the municipality of Campo
Bom (which translates as something along the lines of "Good Field") gets its name from its good pastures and abundance of water, which the drovers who passed by around 1800 encountered, while returning from São Francisco and Vacaria toward the capital. The town is also a pioneer in the manufacturing of shoes, and was the first municipality to export shoes.

The predominance of urban area is evident along the drainage area of Schmidt stream (Figure 1), and there is also a considerable presence of anthropogenic rural area. A wide diversity of land use and occupation, distributed in a heterogeneous and fragmented manner, can be observed (Table 1)

\subsection{Georeferenced systems}

The files needed to build the GIS environment were the following:

Planialtimetric Data - Altimetric data, referring to the contours of the study area, were identified based on the Continuous Vector Cartographic Base of Rio Grande do Sul, available from Universidade Federal do Rio Grande do Sul (Hasenack and Weber, 2010). This base was created through the digitization of topographic maps from the Board of Geographic Service (DSG) of the army and the level curves are in vector format, in a scale of 1:50,000 every 20 meters format Geocentric Rference System of the Americas - Datum SIRGAS 2000.

Pedological and Geological Data - The pedological and geological maps were obtained from the Brazilian Institute of Geography and Statistics. The maps are in vector format, in a Scale of 1:250,000 and were prepared in 1980 and 1981 by the RADAMBRASIL project format South American Datum 1969 - Datum SAD 69 (Brasil, 1982).

Land Use Data - The Land Use Map was also made available by the Brazilian Institute of Geography and Statistics (IBGE, 2010d). The map is in vector format, in

Table 1. Land use and occupation in the Schmidt stream watershed area

\begin{tabular}{llcr}
\hline \multicolumn{1}{c}{ Classes } & Area $\left.\mathbf{( k m}^{2}\right)$ & \multicolumn{1}{c}{$\%$} \\
\hline 01 & Water depth & 0.06 & 0.25 \\
02 & Native Forest & 3.07 & 12.83 \\
03 & Native Forest + Rural & 2.68 & 11.20 \\
& Anthropic & & \\
04 & Rural Anthropic + & 1.28 & 5.35 \\
& Secondary Vegetation & 0.23 & 0.96 \\
05 & Forestry & 9.53 & 39.85 \\
06 & Urban Anthropic/Urban & & \\
& Area & 0.06 & 0.25 \\
07 & Wetlands/Wet Grasslands & 6.29 & 26.30 \\
08 & Rural Anthropic & 0.72 & 3.01 \\
09 & Urbano Anthropic/Areas & & \\
of expansion & Total & 23.92 & \\
\hline
\end{tabular}

Source: Brazilian Institute of Geography and Statistics (IBGE, 2010d). 


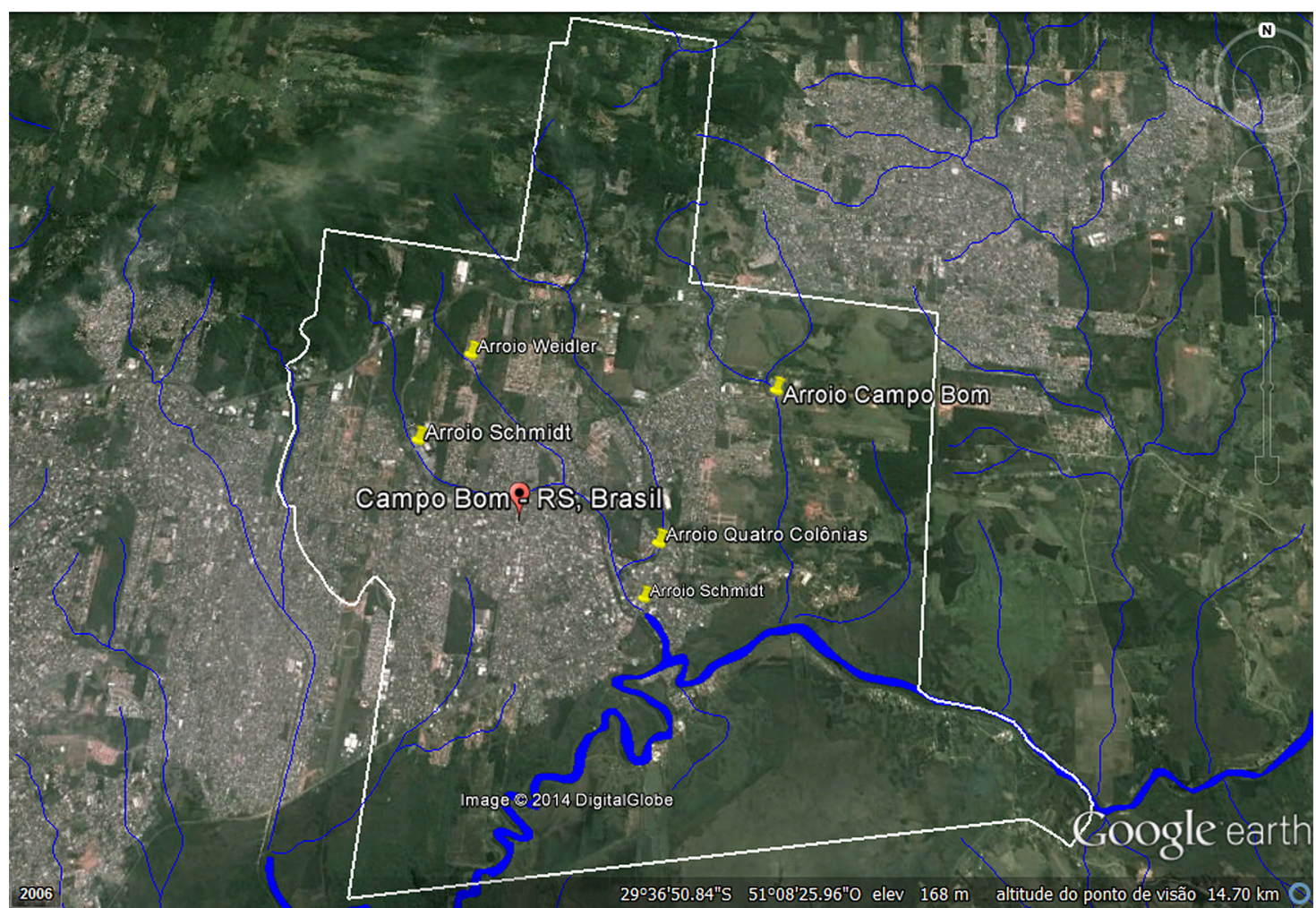

Figure 1. Municipality of Campo Bom (state of Rio Grande do Sul, Brazil) and the location of Schmidt creek. Source: Google Earth (2013) - Date of images: 09/09/2013.

the same scale of 1:100,000 format Geocentric Reference System of the Americas - Datum SIRGAS 2000.

Initially, a compatibility effort was performed with all files in order to create a plan of information that could be associatiated. Thus, using the ArcGIS 10.1 software, all files were georeferenced in Datum SAD 69, i.e., using the same system of coordinates, allowing for the crossing of the files.

Subsequently, the study site was defined by the level curves, in which it was possible to identify the tops of hills, which correspond to the watershed, thereby delimiting the area of contribution to Schmidt stream. With the demarcation of the watershed, themed maps were cut from vectorized data, thus allowing for the identification of the characteristics of the region under scope.

This research conducted a quantitative and qualitative approach involving three stages of work: the first was bibliographic and document research about the theme proposed, as well as about the study site. Cartographic documents were pre-analyzed and later georeferenced and vectorized using the ArcView GIS software. The second stage was the use of the processed data through techniques of digital image processing. Finally, we performed the analysis and description regarding geological and pedological aspects, as well as land use and occupation. In addition, field visits were performed in order to achieve a visual recognition of the study site, aid in the interpretation of the images, and record relevant points using the Global Position Sistem (GPS).

In order to conduct the climatological study, data collected by conventional weather station 83961 - Auxiliary Climatological Station Campo Bom - during the operation period, from April 2003 until March 2013, were used. Data were summarized with descriptive statistics recorded relating to maximum and minimum temperatures, precipitation, intensity and direction of winds, and relative humidity.

\section{Results}

\subsection{Physical characterization of the Schmidt stream watershed area}

The Schmidt stream is one of the main tributaries of the Sinos river, draining part of the town of Campo Bom, a large urban center.

Throughout its drainage area (Figure 2) two other smaller streams flow into Schmidt stream: Weidler stream and Quatro Colônias stream (Figure 1). Thus, in all the characteristics described in the rest of this article, especially in the physical characteristics of the study site, land use and occupation, the area will be regarded as including these two tributaries, since Schmidt stream integrates this drainage area. The total area of the Schmidt stream watershed is $23.92 \mathrm{~km}^{2}$, approximately. 


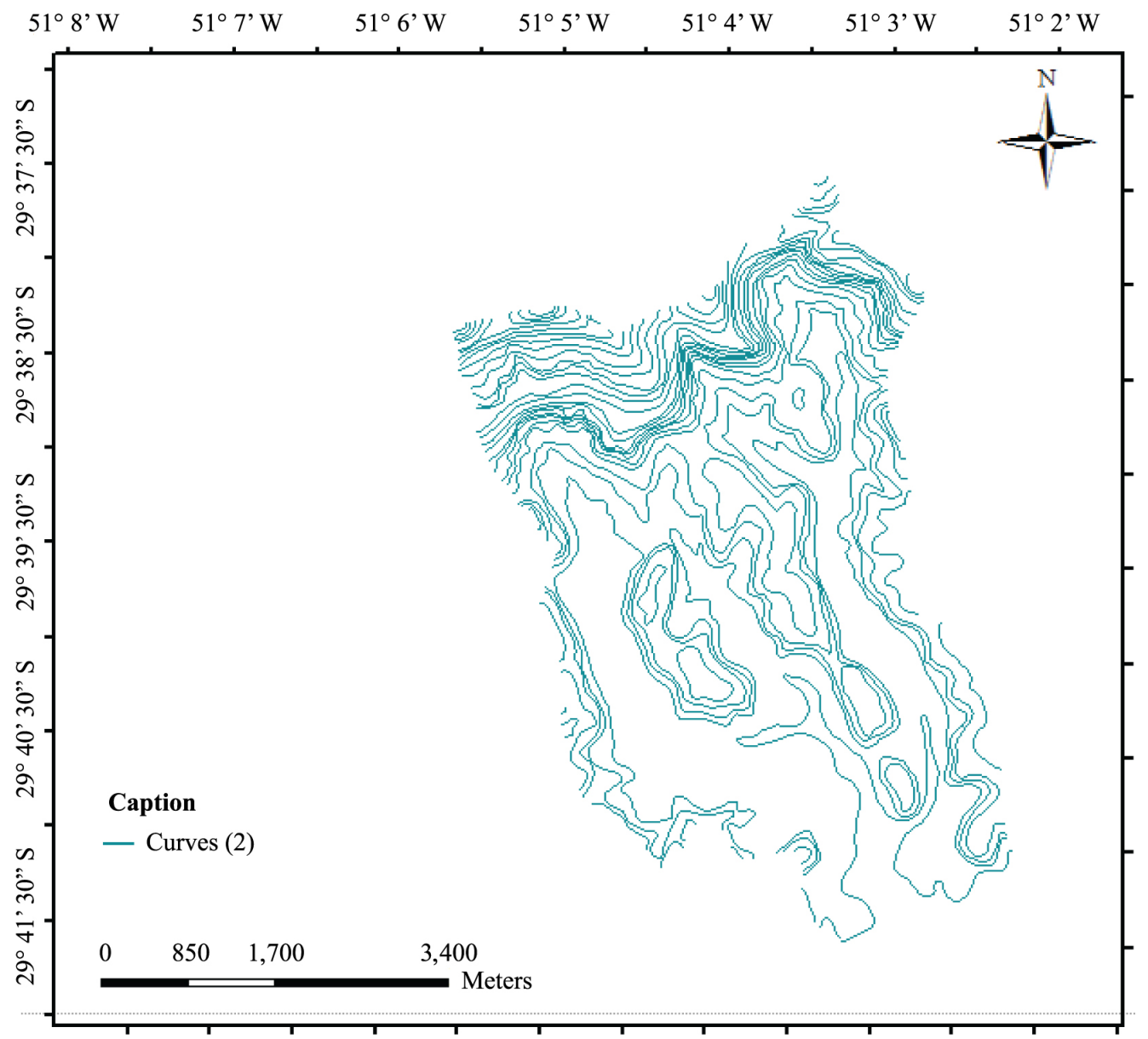

Figure 2. Area of the Schmidt stream watershed as determined by level curves. Datum SIRGAS 2000. Source: Hasenack and Weber (2010).

In the highest region, north, the watershed has a good vegetation cover, predominantly natural or with little anthropic action and various natural characteristics preserved.

However, in the stretch located downstream of the headwaters area, with abundant forest cover, the stream is already showing the formation of shoals that bar the flow of water (Figure 3a). As it moves into the urban area, initially covering a stretch in which part of the industrial area of Campo Bom is located, the stream follows a stretch of bike lane, during which course it has a relatively consisten flow across the width of the stream, with the formation of black sludge at the bottom and edges of the river bed, an intense, pungent and unpleasant smell, with banks covered with short grass, reforestation vegetation and landscaping beautification, in a width of approximately 3 meters on each side, with relatively stable banks. In the stretch under the bridge in the 25 de Julho district (Figure 3b), the stream is channeled only under the bridge and the entry of industrial and domestic sewer wastewater is observed on both sides of the bed, as well as deposits of industrial waste, presence of flies and a very intense unpleasant smell, extensive formation of white foam on the water, unstable banks and evidence of moderate erosion, little vegetation, and, at this point, the stream presents rock formations at the bottom of the bed. At the mouth, before the bridge, the stream presents irregular housing, shoals, one of the banks shows moderate vegetation, the water looks cleaner, significant decrease of the mud found in the bike lane stretch, which makes it possible to observe the presence of tadpoles. Right after this, the stream presents a major widening, with very unstable banks where it meets the Sinos river.

The drainage area is limited, to the west, by the city of Novo Hamburgo, whose waters drain into the São José stream. East of the watershed, on the other hand, it flows following the area of Campo Bom, draining into the Campo Bom stream. To the south, the watershed meets the Sinos river, i.e., the Schmidt stream flows into the Sinos river. At the mouth of Schmidt stream, it presents a widening (Figure 4) of approximately $10 \mathrm{~m}$, caused by the collapse of the bed, which is totally devoid of riparian vegetation, on both banks.

Along its entire course, the stream drains both industrial/ commercial and residential areas. 


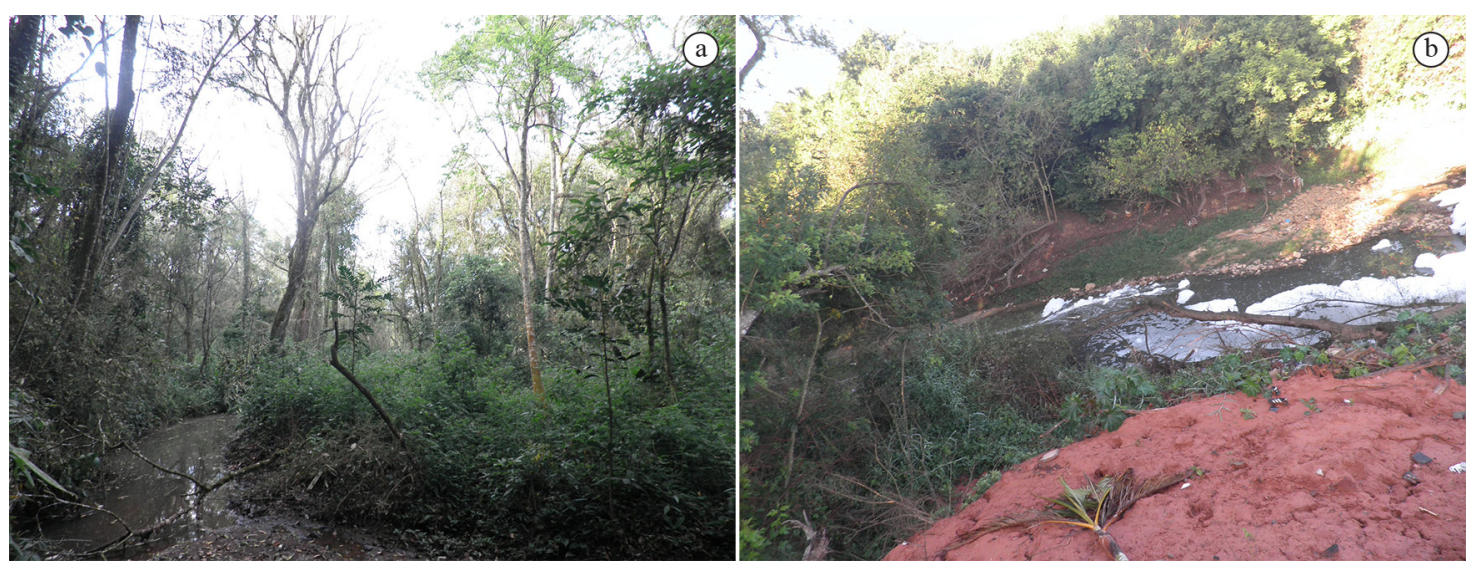

Figure 3. (a) Point below the sources - August, 2012, (b) Point after the bridge, 25 de Julho district, urban area - Campo Bom, Brazil. Source: Baisinos Project (UNIVERSIDADE FEEVALE, 2010).

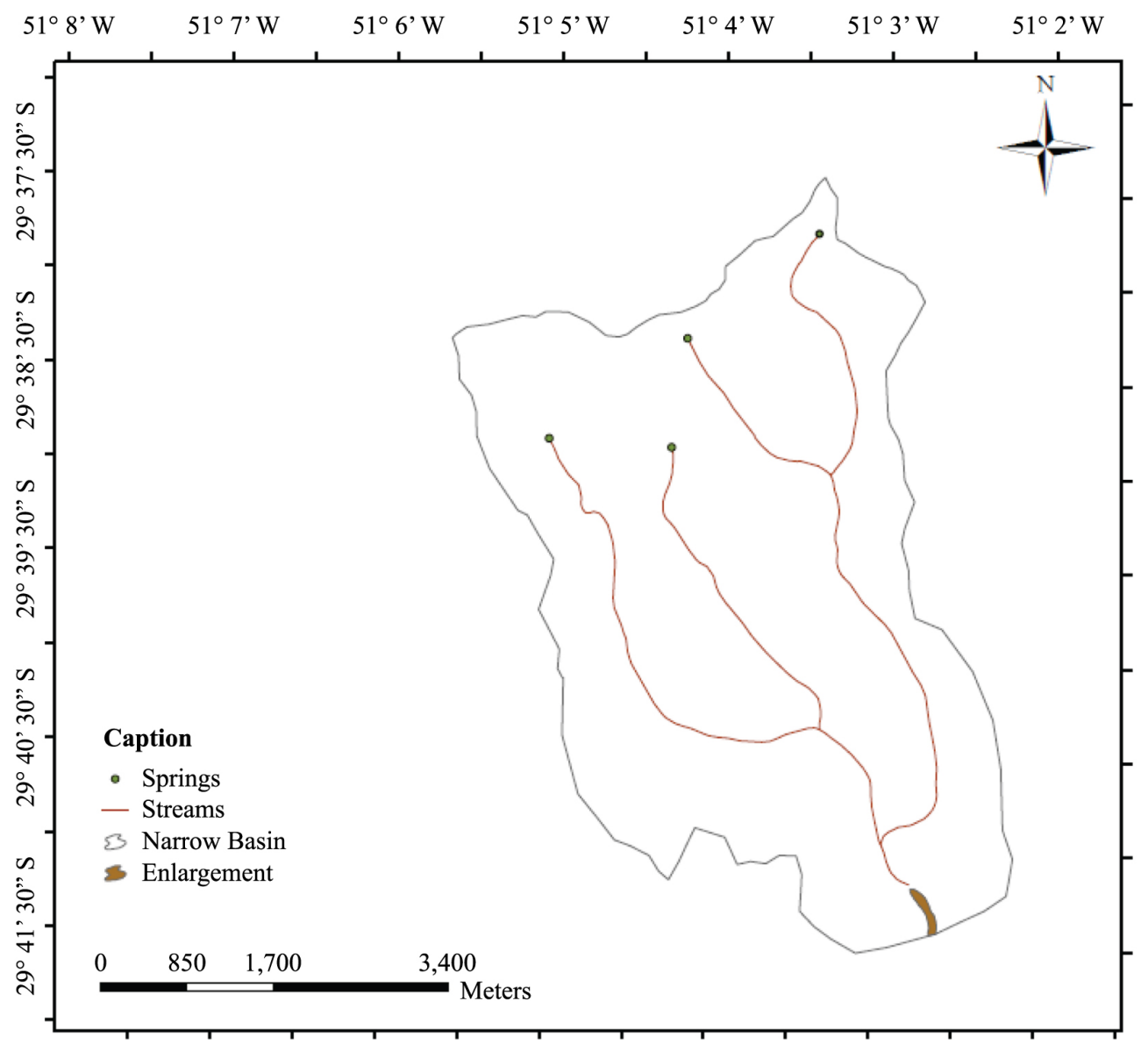

Figure 4. Heads, course of the Schmidt stream, tributary streams and mouth. Datum SIRGAS 2000. Source: Hasenack and Weber (2010).

\subsection{Geological characterization of the study site}

Covering an approximate area of $5.66 \mathrm{~km}^{2}(23.7 \%)$ of the Schmidt stream watershed, the colluvial deposits consist of materials that are derived from the slopes, usually settling near the base. Colluvial soils were carried by gravity, which causes masses of soil and rocks to fall along sloping areas. The watershed also contains a small fraction, less than $0.01 \mathrm{~km}^{2}$, of alluvial deposits, at the final region of the watershed (Figure 5).

Another geological formation present in the area of the Schmidt stream watershed, grass facies, which according to the the CPRM (2004) - Brazilian Geological Survey Service 


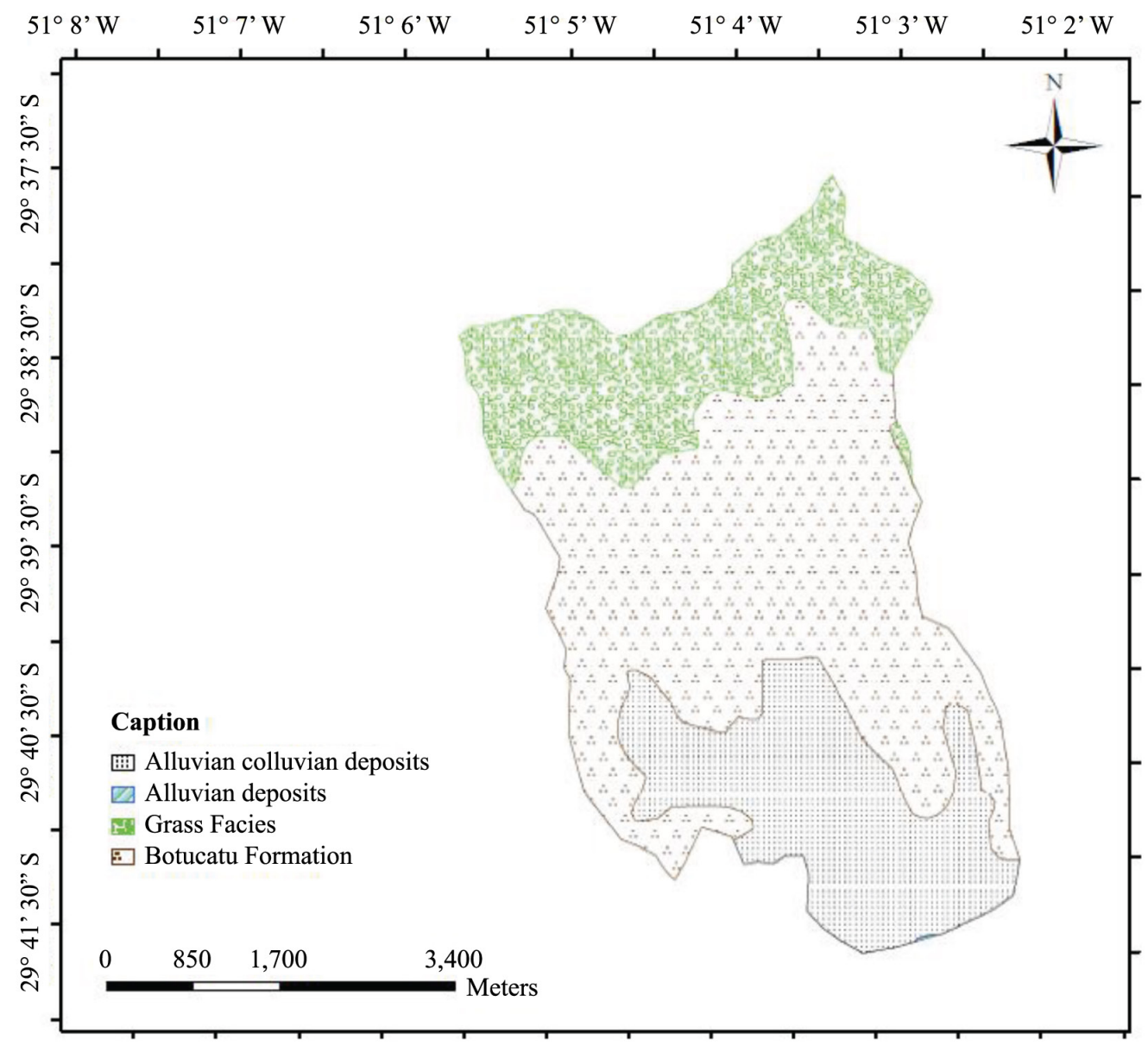

Figure 5. Geological characterization of the Schmidt stream watershed. Datum SAD 69. Source: Brasil (1982).

is characterized by fine to medium granular basalt spills, gray melanocratic, vesicular horizons filled by zeolites, carbonates, apofilites and saponite, structures of base flow, interbedded with Botucatu sandstones. It covers $5.4 \mathrm{~km}^{2}$ $(22.6 \%)$ of the Schmidt stream watershed, at the northern stretch, where the main sources of this stream are located.

The Botucatu Formation underlies an area of approximately $12.86 \mathrm{~km}^{2}(53.7 \%)$ located in the middle part of the watershed, in a now highly urbanized area of the region. This geological formation usually consists of medium to fine sandstones with high sphericity and matte, rosy appearance, which present tangentially, cross-bedded, medium to large stratification. In hydrogeological terms, when incorporating the Guarani Aquifer, this formation ensures excellent hydrodynamic values.

\subsection{Pedologic characterization of the Schmidt stream drainage area}

According to the map of soil conditions (Figure 6), the Schmidt stream watershed basically presents three distinct formations in its drainage area, described as follows.

Sandy Dystrophic Red Argisol and Typical Dystrophic Red Argisol, according to the old EMBRAPA (Santos and Zaroni, 2013), classification, are soils that were oncorporated into the new Brazilian System of Soil Classification as of 2006, and are here characterized simply as argisols.

The watershed under study, an area of $23.31 \mathrm{~km}^{2}$ (97.4\%) of pedological formation classified as argisols are divided into Sandy Dystrophic Red Argisols $\left(11.29 \mathrm{~km}^{2}\right)$ and Typical Dystrophic Red Argisol (12.02 $\left.\mathrm{km}^{2}\right)$.

The argisols are characterized by containing clay, having a sandy texture and consisting of mineral material.

On the other hand, Planosols (a hydromorphic extinct in the new classification because this hydromorphism is only temporary and, therefore, difficult to distinguish in the field) in the watershed of the Schmidt stream account for only $0.61 \mathrm{~km}^{2}$, corresponding to the lower area, i.e., the mouth, near Sinos river.

\subsection{Land use and occupation}

The watershed of Schmidt stream brings together a variety of uses throughout its drainage area. Some of them are overlapping urban and rural areas (Figure 7).

Nine types of land use were mapped in the Schmidt stream drainage area, as described by the respective proportions of each land use and occupation (Table 1). Particularly noteworthy is the presence of native forest $(12.83 \%)+$ rural anthropic (11.20\%) and also rural anthropic 


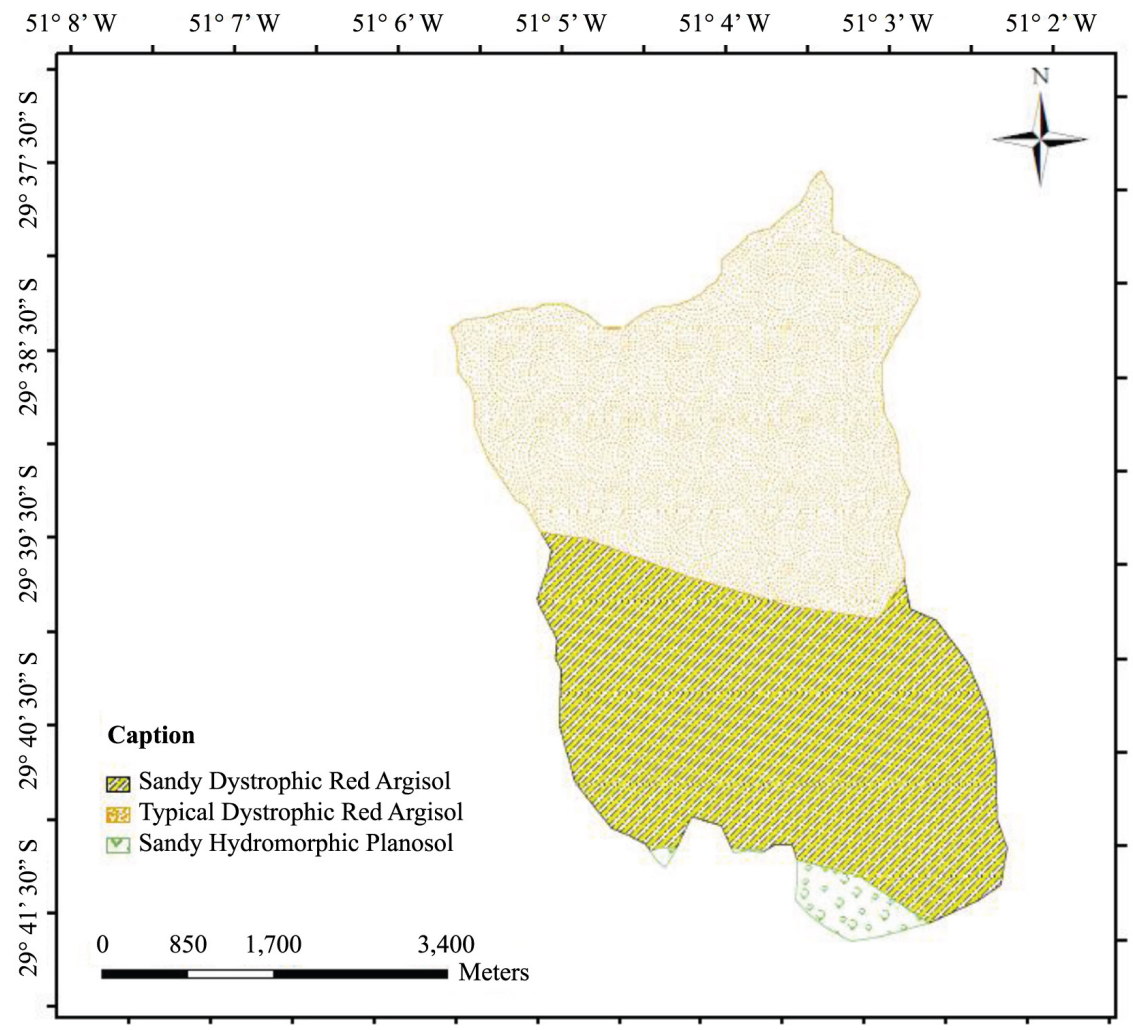

Figure 6. Characterization of soil types in the Schmidt stream watershed. Datum SAD 69. Source: Brasil (1982).

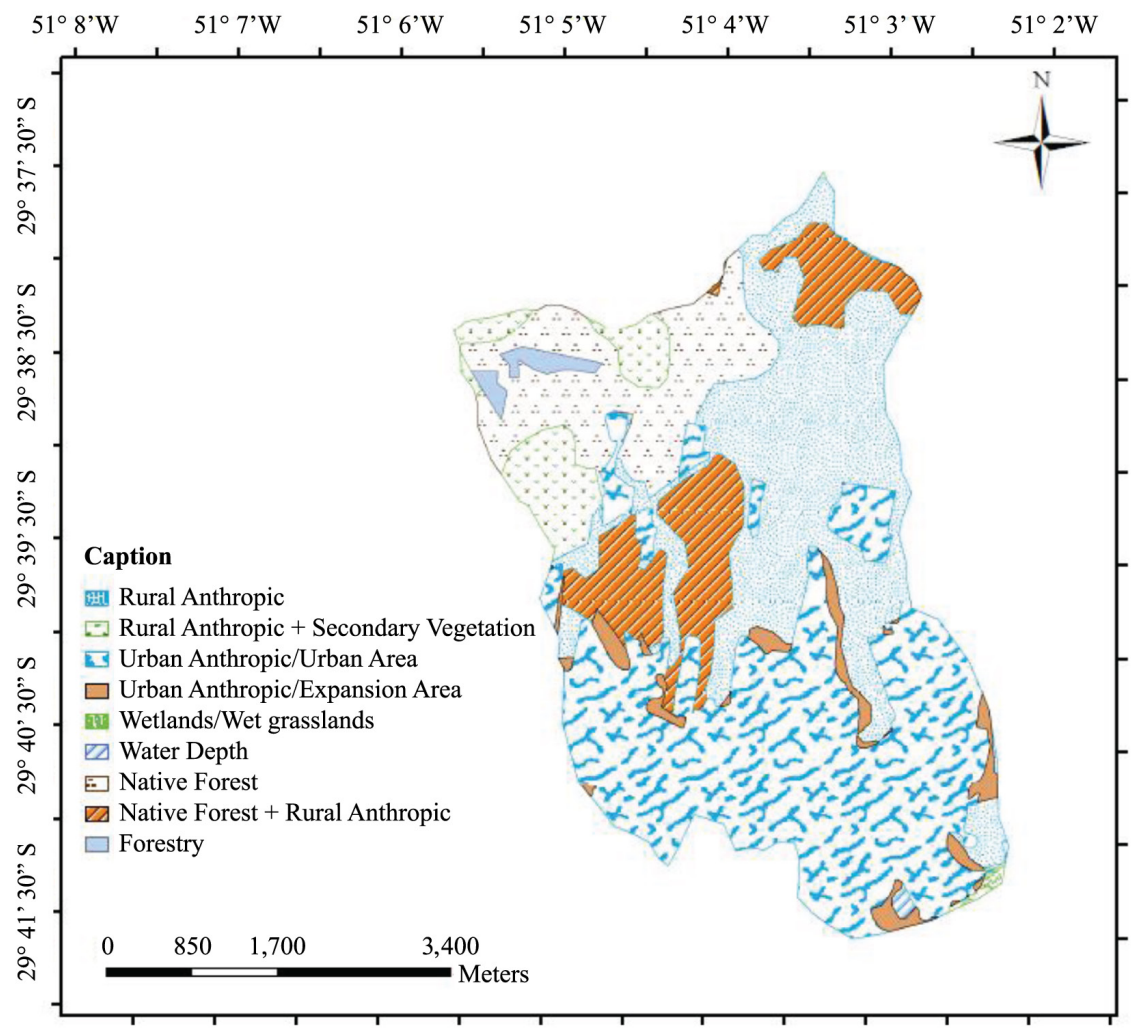

Figure 7. Land use and occupation in the Schmidt stream drainage area. Source: Brazilian Institute of Geography and Statistics (IBGE, 2010g). 
+ secondary vegetation $(5.35 \%)$ in the region where the sources are located. Also, agricultural occupation, in the upper area of the watershed, i.e., Rural Anthropic, occupies $26.30 \%$ of the area.

Note the predominance of urbanization with categories Urban Anthropic/Urban Area (39.85\%) and Urban Anthropic/Areas of expansion (3.01\%), shown along the middle and lower part of the watershed drainage area, and also note the quite pronounced extent of the anthropic rural area $(26.30 \%)$. A great diversity of fragments was observed, characterizing a process of heterogeneous occupation.

The area is characterized by intense industrial activity, especially from the manufacturing industry, including chemical industries, especially targeted at footwear, metalworking, footwear and leather and byproducts, among others (IBGE, 2010e). Environmental problems resulting from these activities include the contamination of soil, water and air, due to emissions and effluent discharges, among others.

In agriculture, the main cultures are garlic, sweet potato, sugar cane, beans, onions, cassava, banana, persimmon, lime, orange, mango, watermelon, cantaloupe, corn and other fruits and vegetables. Environmental problems related to these activities include the pollution of water resources and soil due to the improper use of pesticides, inadequade washing and disposal of packaging, and erosion and siltation caused by poor soil management (IBGE, 2010f).

In terms of forestry, which occupies only $0.96 \%$ of the watershed area, products include firewood and logs for various purposes (IBGE, 2010g).

Animal husbandry is also an economic activity developed in the watershed, however, on a smaller scale. Poultry, dairy cattle, pigs, sheep, horses, beekeeping and fish farming are the main activities in this sector (IBGE, 2010h).

Regarding the flora, according to the study of the forest vegetation published by Atlas of Forest Remnants of the Atlantic Forest (Fundação SOS Mata Atlântica, 2012), for the current survey (2011-2012) of the town of Campo Bom has maintained $3 \%$ of its natural area.

\subsection{Characterization of local biodiversity}

In this case, loss of biodiversity results from alterations in land use and occupation. When the original vegetation cover is removed, the richness and diversity of species of an ecosystem is generally reduced drastically, thus affecting the faunal composition of the area. This information is verifiable through the images of land use and occupation
(Figure 7), which underwent anthropic activity with different uses, replacing the natural biome. Based on the study of various reports and on the field assessment, a few possible environmental problems can be pointed out.

In general, it is possible to underscore aspects related to the management of soil, water resources and local biodiversity management. These aspects are related to human activities that cause environmental impacts. Among these impacts, it is possible to point out erosion along the bed, lack of riparian vegetation and siltation of the stream's bed; alteration of lotic and lentic characteristics due to the removal of clay and inadequate waste disposal; backfill and drainage of wetlands; chemical pollution from industrial and domestic sewage; loss of biodiversity (fauna and flora) among others.

\subsection{Climatology of the Schmidt stream watershed}

The Campo Bom Auxiliary Climatological Station, located in Campo Bom, Brazil, has submitted the following location data: $25.8 \mathrm{~m}$ altitude, $29^{\circ} 41^{\prime} \mathrm{S}$ latitude, and $51^{\circ} 03^{\prime} \mathrm{W}$ longitude, relying on a historical series of more than 60 years of daily data collection. Data used in this analysis were from April 2003 to March 2013.

With an annual mean of $1337 \mathrm{~mm}$, minimum rainfall occurs in November, although in the monthly mean for the 10 years, the lowest average verified was in April. Rainfall shows a very marked variability, and it cannot be clearly established whether any period has more intense rainfall, except for the month of September, when rainfall intensifies (Table 2), (Figure 8).

The maximum temperatures range between $10.5^{\circ} \mathrm{C}$ and $41.6^{\circ} \mathrm{C}$ and the minimum temperatures range between $-1.8^{\circ} \mathrm{C}$ and $26^{\circ} \mathrm{C}$, with lower temperatures generally recorded in early morning. There is a great daily variation in temperature (Figure 9).

Between April and September, from the end of fall, through the winter and early spring, the lowest temperatures of the year are recorded.

The monthly mean relative humidity follows an upward trend in the final months of the fall and in the beginning of winter, maintaining minimally lower values in summer (Table 3).

Regarding the winds, considering three daily checks: 12:00 AM, 12:00 PM and 6:00 PM, predominantly, we observe almost no wind. When winds blow, their most frequent directions are southeast, south, southwest and west. Also noteworthy is the manifestation of the north

Table 2. Characterization of rainfall (mm) in the period from 2003 to 2013.

\begin{tabular}{lrrrrrrrrrrrr}
\hline & \multicolumn{1}{c}{ Jan } & \multicolumn{1}{c}{ Feb } & \multicolumn{1}{c}{ Mar } & \multicolumn{1}{c}{ Apr } & \multicolumn{1}{c}{ May } & \multicolumn{1}{c}{ June } & \multicolumn{1}{c}{ July } & \multicolumn{1}{c}{ Aug } & \multicolumn{1}{c}{ Sept } & \multicolumn{1}{c}{ Oct } & \multicolumn{1}{c}{ Nov } & Dec \\
\hline Total & 1203.6 & 1480.6 & 1209.5 & 1123.1 & 1244.9 & 1162.5 & 1629.4 & 1292.7 & 1828.8 & 1405.7 & 1227.1 & 1238.9 \\
Mean & 120.4 & 148.1 & 121.0 & 112.3 & 124.5 & 116.3 & 162.9 & 129.3 & 182.9 & 140.6 & 122.7 & 123.9 \\
S & 55.9 & 70.1 & 36.0 & 75.7 & 55.6 & 58.8 & 66.8 & 71.5 & 88.7 & 64.8 & 86.1 & 67.4 \\
CV & 46.4 & 47.3 & 29.7 & 67.4 & 44.6 & 50.6 & 41.0 & 55.3 & 48.5 & 46.1 & 70.2 & 54.4 \\
Max. & 219.3 & 266.4 & 172.0 & 296.8 & 200.2 & 240.7 & 281.0 & 245.8 & 368.1 & 240.2 & 302.9 & 266.5 \\
Min. & 50.0 & 31.7 & 58.1 & 25.0 & 42.8 & 37.3 & 82.3 & 45.1 & 66.3 & 41.1 & 16.4 & 43.6 \\
\hline
\end{tabular}

Source: Campo Bom Climatological Station (INMET, 2013). 


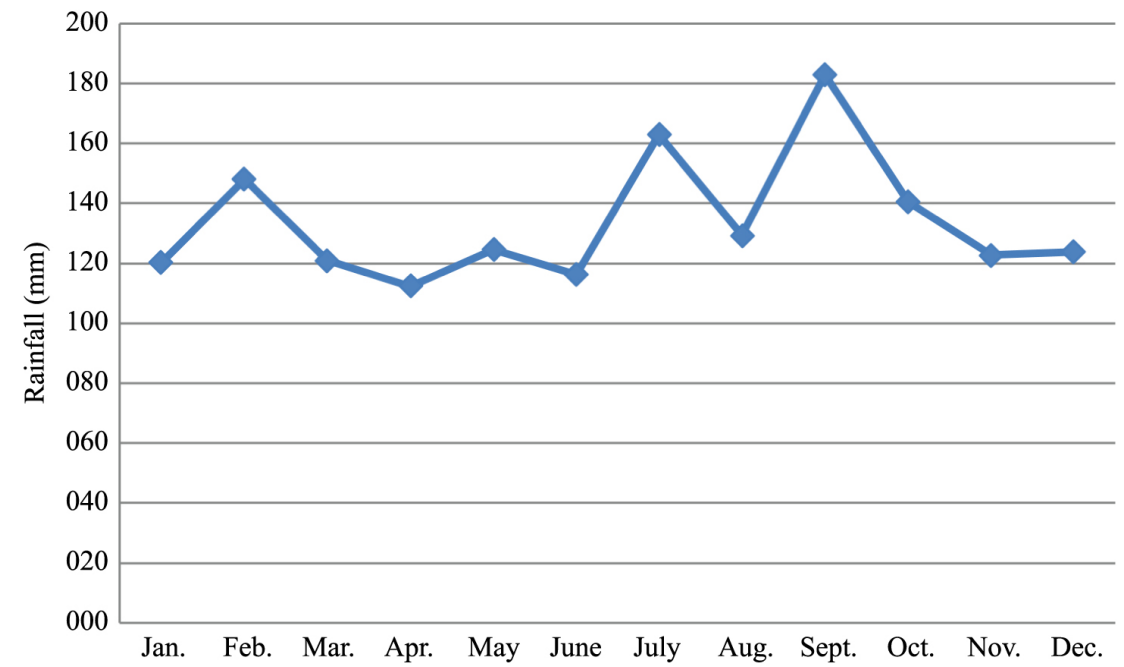

Figure 8. Mean annual variability of rainfall - 2003 to 2013. Source: Campo Bom Climatological Station (INMET, 2013).
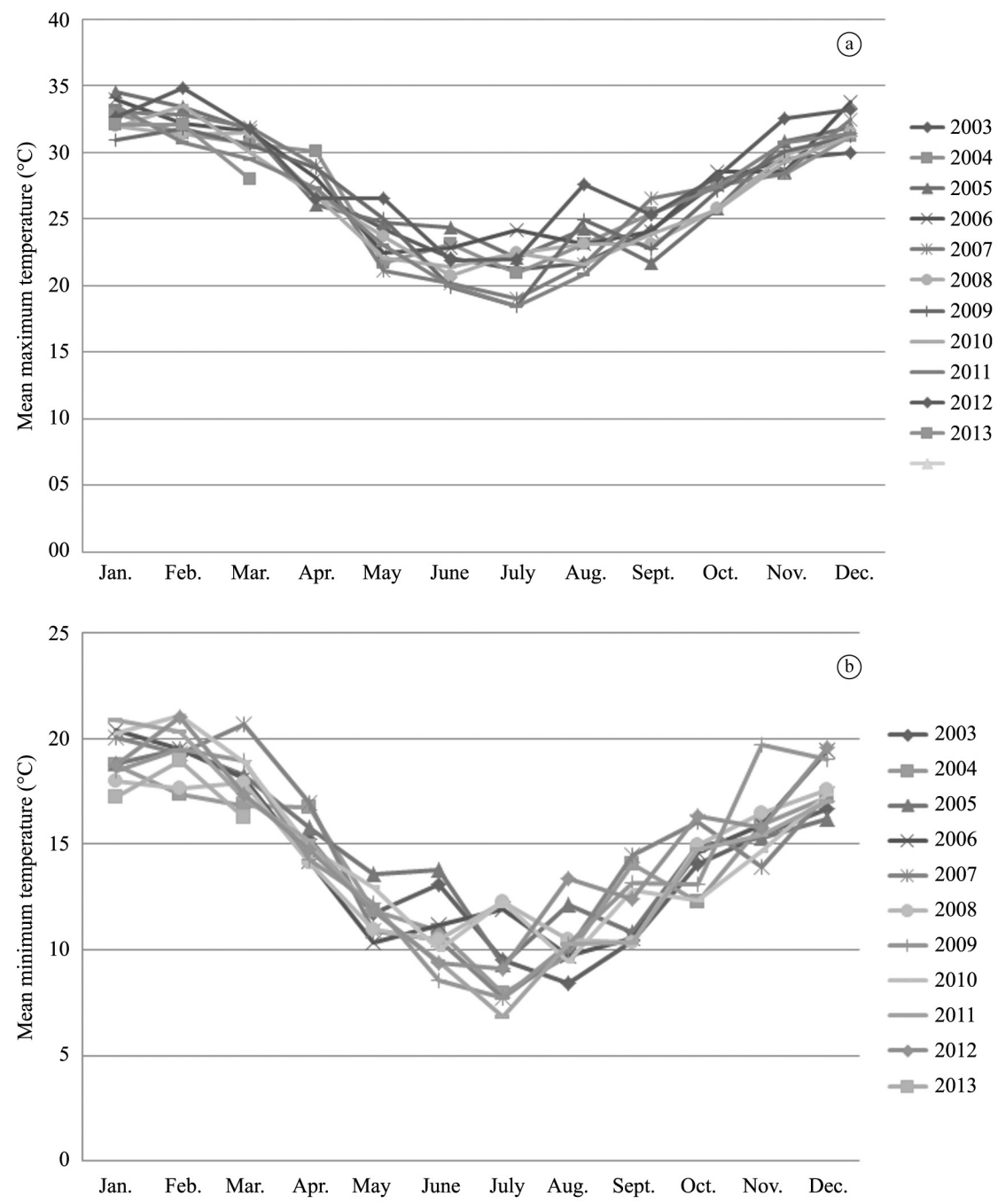

Figure 9. Characterization of the temperature at the Schmidt stream watershed - 2003 to 2013 (a) Maximum mean temperature, (b) Minimum mean temperature. Source: Campo Bom Climatological Station (INMET, 2013). 
wind, which generally leads to the formation of rainfall (Figure 10).

The analysis of wind speeds, considering the classification adopted by the World Meteorological Organization (WMO, 2008) showed that winds have low speed (Table 4). They are generally weak, with speeds under $5 \mathrm{~m} / \mathrm{s}$; although there are short bursts that can reach up to $13.8 \mathrm{~m} / \mathrm{s}$, in some cases.

\section{Discussion}

The Schmidt stream watershed presents various forms of land use and occupation, as well as various levels of compromise. Land use and occupation in the Schmidt stream drainage area play an important role in surface runoff and sediment delivery, as well as in the chemical and organic pollution in the bed, thus affecting the quality and availability of water.

Because of the geological formation (Serra Geral Formation), with basalt outcrops and boulders along the northern drainage area, there is exploitation and processing of basalt rocks, which constitutes a particular land use in the watershed, according to the Sinos River Basin Plan, and the town of Campo Bom is rated as a "Municipality with High Criticality" in terms of mining. The colluvial-alluvial plains found in the final stretch of the watershed (Figure 5) show a tendency to relatively minor erosion due to less steep slopes, however, there is a risk of soil and surface water and groundwater contamination in the event of inadequate sewage discharges and leaks. Colluvial deposits, mostly mass movements, cover the middle and lower sections of the slopes and increase in thickness as the steepness decreases, coming in contact with the alluvion deposited by the body of water in the bottom of the valley (Bigarella et al., 2008, p. 203).

Botucatu sandstones, in turn, generally decompose in infertile, sandy soils, which can lead to extensive coverage of rosy, reddish, loose sand (Washburne, 1930 apud Carneiro, 2007), so the central area of the watershed (Figure 5) can present with sharp erosion, due to neglected care involving the activities performed in the watershed, associated with intense rainfall in the basin, which has an annual mean rainfall index of $1337 \mathrm{~mm}$, helping the flow and transport of large amounts of organic and inorganic sediment loads into the bed of the stream. These are deposited in areas of less steep slopes, obstructing the stream with washed down sediment, thus compromising the quality and quantity of surface water.

The Brazilian agricultural development and the rapid growth of cities, characterized by intensive use of natural resources, usually with no planning and knowledge of soil characteristics, has caused great losses of soil in agriculture and other various losses in urban areas, whether economic, environmental, social, and others. As for the types of soils found in the watershed area, argisols are responsible for the largest coverage area. According to

Table 3. Relative humidity (\%) - mean monthly values from 2003 to 2013.

\begin{tabular}{lllllllllllll}
\hline \multicolumn{1}{c}{ Time } & Jan & Feb & Mar & Apr & May & June & July & Aug & Sept & Oct & Nov & Dec \\
\hline 12:00 AM & 84.1 & 85.3 & 86.9 & 89.7 & 90.8 & 90.6 & 88.9 & 87.3 & 87.0 & 86.1 & 83.2 & 81.9 \\
12:00 PM & 77.6 & 82.0 & 87.5 & 91.9 & 94.1 & 92.3 & 91.3 & 88.8 & 85.9 & 79.5 & 73.6 & 72.1 \\
6:00 PM & 57.1 & 59.6 & 59.0 & 61.0 & 64.9 & 67.4 & 65.6 & 61.9 & 62.1 & 59.3 & 55.9 & 55.1 \\
\hline
\end{tabular}

Source: Campo Bom Climatological Station (INMET, 2013).

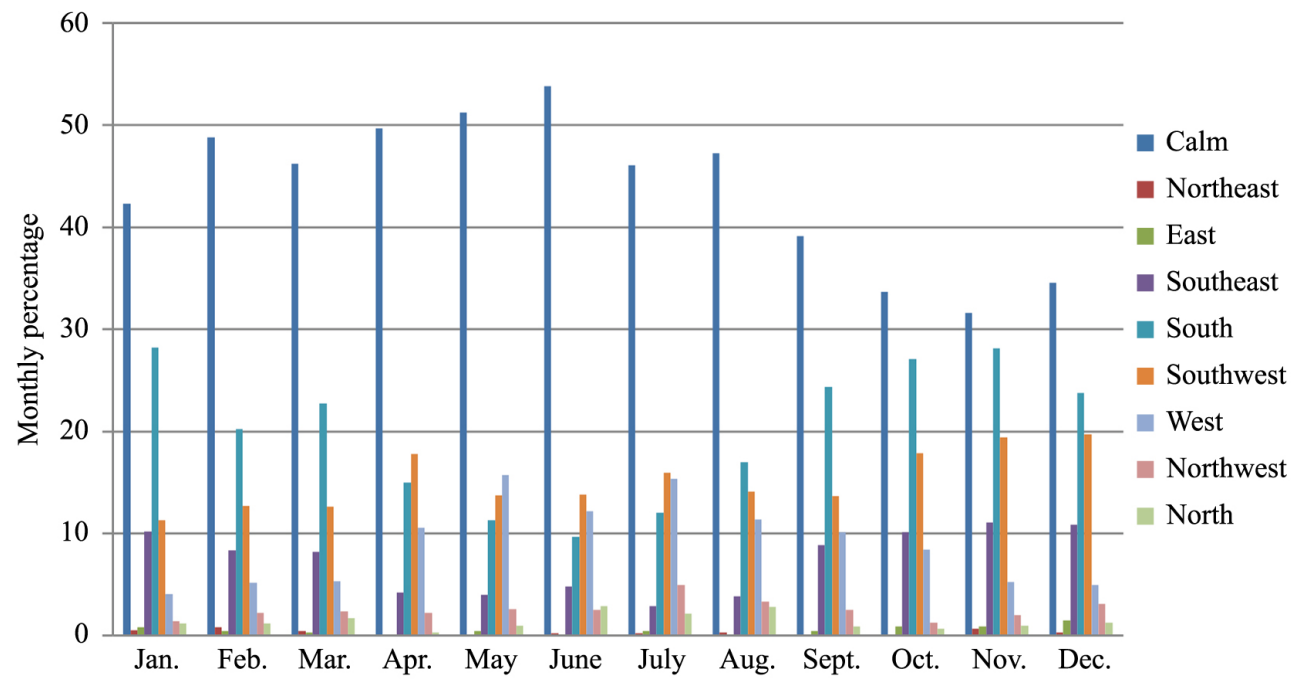

Figure 10. Wind direction in the Schmidt stream watershed - Daily Observations, 2003-2013. Source: Campo Bom Climatological Station (INMET, 2013). 
Table 4. Wind speed (m/s) - Monthly percentage and daily checks, 2003-2013.

\begin{tabular}{lccccccccccccc}
\hline & m/s & Jan & Feb & Mar & Apr & May & June & July & Aug & Sept & Oct & Nov & Dec \\
\hline Cal & $0-0.2$ & 393 & 414 & 427 & 448 & 476 & 484 & 428 & 439 & 352 & 314 & 284 & 321 \\
Light air & $0.3-1.5$ & 148 & 121 & 152 & 125 & 144 & 124 & 164 & 156 & 150 & 158 & 190 & 160 \\
Light breeze & $1.6-3.3$ & 357 & 294 & 317 & 309 & 271 & 257 & 294 & 274 & 343 & 416 & 373 & 396 \\
Gentle breeze & $3.4-5.4$ & 28 & 20 & 26 & 13 & 28 & 28 & 36 & 44 & 45 & 35 & 40 & 49 \\
Moderate breeze & $5.5-7.9$ & 0 & 0 & 0 & 2 & 6 & 3 & 2 & 2 & 1 & 4 & 4 & 3 \\
Fresh breeze & $08-10.7$ & 1 & 0 & 2 & 3 & 5 & 4 & 6 & 13 & 9 & 3 & 6 & 1 \\
Strong breeze & $10.8-13.8$ & 0 & 0 & 0 & 0 & 0 & 0 & 0 & 2 & 0 & 0 & 3 & 0 \\
Near gale & $13.9-17.1$ & 0 & 0 & 0 & 0 & 0 & 0 & 0 & 0 & 0 & 0 & 0 & 0 \\
Gale & $17.2-20.7$ & 0 & 0 & 0 & 0 & 0 & 0 & 0 & 0 & 0 & 0 & 0 & 0 \\
Strong gale & $20.8-24.4$ & 0 & 0 & 0 & 0 & 0 & 0 & 0 & 0 & 0 & 0 & 0 & 0 \\
Storm & $24.5-28.4$ & 0 & 0 & 0 & 0 & 0 & 0 & 0 & 0 & 0 & 0 & 0 & 0 \\
Violent Storm & $28.5-32.6$ & 0 & 0 & 0 & 0 & 0 & 0 & 0 & 0 & 0 & 0 & 0 & 0 \\
\hline
\end{tabular}

Source: Campo Bom Climatological Station (INMET, 2013).

Pedron et al. (2007), argisols have restricted potential for use in urban construction, and are ideal for use in green and recreational areas, due to limitations such as soil depth, drainage and geologic material. In the study area, a predominance of urban and rural occupation was observed in the area corresponding to argisols (Figures 5 and 6), which reinforces the need for taking precautions in these occupations and justifies the various shoals observed along Schmidt stream. Still, according to Cunha and Guerra (2003), argisols are characterized by the B textural horizon (Bt), marked by an accumulation of clay, illuviation, inner lateral translocation or formation in the horizon itself. In general, there are significant differences in clay content between the A and B horizons, going from a more sandy surface horizon to a more clayey subsurface horizon. This feature may represent a barrier to water seepage along the profile, decreasing its permeability and favoring the surface and subsurface flow in the contact zone between different materials. Moreover, the Schmidt stream watershed is characterized by intense urbanization, with wide occurrence of soil sealing for driveways, asphalt, etc., thus providing low water infiltration into the soil, thereby enhancing the runoff process and causing erosion and/or sedimentation in drainage networks downstream or flooding in the lower regions, affecting riverside communities.

According to Santos and Zaroni (2013), Planosols are characterized by loss of clay in the surface portion and intense accumulation of clay in the subsurface horizon, a sandy surface texture, slow permeability, usually due to accumulation of clay, sandy surface texture, moisture retention, nutrient deficiency, high levels of sodium, harmful levels of aluminum and requiring careful draining and liming. Because of these characteristics, areas with this type of formation should not undergo urbanization, and should be conserved as wetlands or wet grassland areas instead.

Another important aspect regarding land use and occupation and impacts on local biodiversity is chemical pollution from industrial and domestic sewage, as pointed out by Robaina et al. (2002), whose study reported a moderate contamination by zinc and lead in Schmidt stream.

The scope of the watershed is demographically dense and continues to increase in urbanization, according to IBGE (2010i). In terms of housing, this also involves an increases in irregular occupations, with poor physical conditions and urban structure, generating all form of environmental impacts.

Research in the Sinos river basin also points to the importance of maintaining wetlands fragments, even in small stretches, since a study of macrophytes and macroinvertebrates has shown that the composition was not related to the size of the wetlands, suggesting that "[...] environmental policies aimed at conserving biodiversity should also include management actions focused on protecting small wetland areas [...]" (Maltchik et al., 2010, p. 1183). However, a relatively large occupation of wetland is classified in the map (Figure 6 and 7) as an area of Urban Anthropic/ area of expansion.

Considering the extent of the activities and urban soil interferences in the watershed, in terms of to argisols, caution must be exercised in relation to the possible damages from eroding processes, against which the bed of the Schmidt stream must be protected. Caution must also be exercised in agricultural practices and erosion of urban areas, as well as in building constructions.

Regarding the climatic factors analyzed, temperature, relative humidity, wind speed and direction, no extreme situations were observed, and a homogeneous behavior was observed for the period of over 10 years of data under study. The mean monthly rainfall remains at a relatively constant volume. However, it presents a high degree of variation (Table 2). Under the hydrologic concept, the Schmidt stream watershed suffers the greatest interference at runoff, with high sensitivity to the intense, short rains, causing the flooding of areas, which are found and reported frequently by the local population. However, when the flow decreases substantially when rainfall stops. Alterations resulting from improper land use and occupation, especially in sensitive areas, such as the illegal occupation of wetlands and 
removal of riparian vegetation, for example, are detected at several points across the watershed.

Bieger et al. (2010), in a study of biomonitoring via aquatic macroinvertebrates, has observed that the water quality in the streams of the Sinos river basin has not varied from the winter to the summer, suggesting that there would be no oscillations in the aspect of water quality associated with environmental temperature fluctuations. However, their study has detected a much worse quality of water in the lower basin, which includes the Schmidt stream, because of the heavily urbanized and industrialized area.

The use of GIS was found to be critical in the process of assessment and characterization of river basins and watersheds. However, the use of aerial imagery for the purpose of monitoring and planning is limited mainly by the cost of acquiring the images. The availability of research data and continuous monitoring and images from official bodies would certainly allow for very promising results.

\section{Acknowledgements}

Special thanks to INMET - National Institute of Meteorology for providing the data from the climatological station of Campo Bom-RS, which was required in order to develop this work.

\section{References}

BIEGER, L., CARVALHO, A.B.P., STRIEDER, M.N., MALTCHIK, L. and STENERT, C. 2010. Are the streams of the Sinos River basin of good water quality? Aquatic macroinvertebrates may answer the question. Brazilian Journal of Biology $=$ Revista Brasileira de Biologia, vol. 70, no. 4, suppl., pp. 1207-1215.

BIGARELLA, J.J., BECKER, R.D. and SANTOS, G.F., 2008. Estrutura e origem das paisagens tropicais e subtropicais. 2nd ed. Florianópolis: Editora da UFSC.

BRASIL. Ministério das Minas e Energia. Secretaria Geral, 1982. Folha SD. 23 Brasilia: geologia, geomorfologia, pedologia, vegetação, uso potencial da terra - Projeto RADAMBRASIL. Rio de Janeiro: Ministério das Minas e Energia. 660 p. Levantamento de Recursos Naturais, vol. 29.

CALIJURI, M.C. and BUBEL, A.P.M., 2006. Conceituação de microbacias. In: W.P. LIMA and M.J.B. ZAKIA, orgs. As florestas plantadas e a água: implementando o conceito da microbacia hidrográfica como unidade de planejamento. São Carlos: Rima. 226 p.

CARNEIRO, C.D.R., 2007. Viagem virtual ao Aqüífero Guarani em Botucatu (SP): formações Pirambóia e Botucatu, Bacia do Paraná. Terra e Didatica, vol. 30, no. 1, pp. 50-73.

COMPANHIA DE PESQUISA DE RECURSOS MINERAIS CPRM, Serviço Geológico do Brasil, 2004 [viewed 4 December 2013]. Aparados [online]. Available from: www.cprm.gov.br

CUNHA, S.B. and GUERRA, A.J.T., 2003. Degradação ambiental. In: A.T. GUERRA and S.B. CUNHA, orgs Geomorfologia e meio ambiente. Rio de Janeiro: Bertrand Brasil, pp. 184-185.

DALMOLIN, R.S.D. and PEDRON, F.A., 2004. Distribuição dos solos no ambiente. In: A.C. AZEVEDO, R.S.D. DALMOLIN and F.A. PEDRON, orgs. Solos \& Ambiente: I Fórum Solos \& Ambiente. Santa Maria: Editora Pallotti, pp. 23-39.

DONHA, A.G., SOUZA, L.C.P. and SUGAMOSTO, M.L., 2006. Determinação da fragilidade ambiental utilizando técnicas de suporte à decisão e SIG. Revista Brasileira de Engenharia Agrícola e Ambiental, vol. 10, no. 1, pp. 175-181. http://dx.doi. org/10.1590/S1415-43662006000100026.

EMPRESA BRASILEIRA DE PESQUISAAGROPECUÁRIAEMBRAPA. Centro Nacional de Pesquisa em Solos, 1999. Sistema Brasileiro de Classificação de solos. Brasília: Embrapa. 412 p.

FUNDAÇÃO SOS MATA ATLÂNTICA. Instituto Nacional de Pesquisas Espaciais, 2012 [viewed 3 March 2014]. Lista do desmatamento período 2011-2012 [online]. Available from: http://mapas.sosma.org.br/site_media/download/estatisticas/ lista_municipios_desflorestamento_2011_2012.pdf

GOOGLE EARTH, 2013 [viewed 15 January 2014]. Campo Bom - RS [online]. Available from: http://mapas.google.com

GUERRA, A.J.T., 1999. O início do processo erosivo. In: A.J.T. GUERRA, A.S. SILVA and R.G.M. BOTELHO, orgs. Erosão e conservação dos solos: conceitos, temas e aplicações. Rio de Janeiro: Bertrand Brasil, cap. 1, pp. 272-293.

HASENACK, H. and WEBER, E., orgs., 2010. Base cartográfica vetorial contínua do Rio Grande do Sul - escala 1:50.000. Porto Alegre: UFRGS. Série Geoprocessamento, no. 3. DVD-ROM.

INSTITUTO BRASILEIRO DE GEOGRAFIA E ESTATÍSTICAIBGE, 2010a [viewed 4 January 2014]. Cidades [online]. Available from: http://cidades.ibge.gov.br/xtras/perfil.php?lang=\&codmu $\mathrm{n}=430390$ \&search=rio-grande-do-sul|campo-bom

INSTITUTO BRASILEIRO DE GEOGRAFIA E ESTATÍSTICA - IBGE, 2010b [viewed 4 January 2014]. Cidades - Histórico [online]. Available from: http://cidades.ibge.gov.br/painel/ historico.php?lang=\&codmun=430390\&search=rio-grande-dosul|campo-bom|infograficos:-historico

INSTITUTO BRASILEIRO DE GEOGRAFIA E ESTATÍSTICA - IBGE. 2010c [viewed 4 January 2014]. Cidades - Histórico [online]. Available from: http://cidades.ibge.gov.br/painel/historico. php?lang=\& codmun=430390\&search=rio-grande-do-sul|campobom|infograficos:-historico

INSTITUTO BRASILEIRO DE GEOGRAFIA E ESTATÍSTICA - IBGE. 2010d [viewed 20 October 2013]. Mapas da cobertura e uso da terra dos estados do Rio Grande do Sul [online]. Available from: http://geoftp.ibge.gov.br/mapas_tematicos/uso_da_terra/ cartas_escala_250mil/estaduais/RS/

INSTITUTO BRASILEIRO DE GEOGRAFIA E ESTATÍSTICA - IBGE. 2010e [viewed 15 January 2014]. Cidades@:Campo Bom [online]. Available from: http://cidades.ibge.gov.br/xtras/temas. php?lang $=\&$ codmun $=430390 \&$ idtema $=88 \&$ search $=$ rio-grande-dosul|campo-bom/estatisticas-do-cadastro-central-de-empresas-2010

INSTITUTO BRASILEIRO DE GEOGRAFIA E ESTATÍSTICA - IBGE. 2010f [viewed 15 January 2014]. Cidades@:Campo Bom [online]. Available from: http://cidades.ibge.gov.br/xtras/ temas.php?lang $=\&$ codmun $=430390 \&$ idtema $=18 \&$ search $=$ riogrande-do-sul|campo-bom|producao-agricola-municipal-cereaisleguminosas-e-oleaginosas-2007

INSTITUTO BRASILEIRO DE GEOGRAFIA E ESTATÍSTICA - IBGE. 2010g [viewed 20 October 2013]. Mapas da cobertura e uso da terra dos estados do Rio Grande do Sul [online]. Available from: http://geoftp.ibge.gov.br/mapas_tematicos/uso_da_terra/ cartas_escala_250mil/estaduais/RS/ 
INSTITUTO BRASILEIRO DE GEOGRAFIA E ESTATÍSTICA - IBGE. 2010h [viewed 15 January 2014]. Cidades@: Campo Bom [online]. Available from: http://cidades.ibge.gov.br/xtras/ temas.php?lang $=\&$ codmun $=430390 \&$ idtema $=72 \&$ search $=$ riogrande-do-sul|campo-bom|pecuaria-2010

INSTITUTO BRASILEIRO DE GEOGRAFIA E ESTATÍSTICA -IBGE.2010i [viewed 15 January 2014].Cidades@:Campo Bom [online]. Available from: http://cidades.ibge.gov.br/xtras/perfil.ph p?lang $=\&$ codmun $=430390 \&$ search $=$ rio-grande-do-sul|campo-bom

INSTITUTO NACIONAL DE METEOROLOGIA - INMET, Banco de Dados Meteorológicos para Ensino e Pesquisa - BDMEP [online], 2013 [viewed 15 January 2014]. Available from: http:// www.inmet.gov.br/projetos/rede/pesquisa/

LEONARDO, H.C.L., 2003. Indicadores de qualidade de solo e água para avaliação do uso sustentável da microbacia hidrográfica do Rio Passo CUE, região oeste do Estado do Paraná. Piracicaba: Escola Superior de Agricultura Luiz de Queiroz, Universidadede São Paulo, 121 p. Dissertação de Mestrado em Recursos Florestais.

MALTCHIK, L., ROLON, A.S. and STENERT, C., 2010. Aquatic macrophyte and macroinvertebratediversity and conservation in wetlands of Sinos River basin. Brazilian Journal of Biology = Revista Brasileira de Biologia, vol. 70, no. 4, pp. 1179-1184. http://dx.doi.org/10.1590/S1519-69842010000600007.
PEDRON, F. A., DALMOLIN, R.S.D., AZEVEDO, A.C., BOTELHO, M.R. and MENEZES, F.P., (2007). Levantamento e classificação de solos em áreas urbanas: importância, limitações e aplicações. Revista Brasileira de Agrociência, vol. 13, no. 2, pp. 147-151.

ROBAINA, L.E.S., PIRES, C.A.F. and FORMOSO, M.L.L., 2002. Metais pesados nos sedimentos correntes, como indicadores de risco ambiental - Vale dos Sinos, RS. Revista do Instituto Geológico, vol. 23, no. 2, pp. 35-47.

SANTOS, H.G. and ZARONI, M.J., 2013. Sistema Brasileiro de Classificação de Solos. 3rd ed. Brasília: Embrapa. 353 p.

TUNDISI, J.G., 2003. Água no século XXI: enfrentando a escassez. São Carlos: RIMA/IIE.

UNIVERSIDADE FEEVALE, 2010. Gestão da qualidade e quantidade de água de quatro microbacias hidrográficas representativas urbanas e rurais do vale do Rio dos SinosBAISINOS. Novo Hamburgo: FEEVALE.

WORLD METEOROLOGICAL ORGANIZATION - WMO, 2008. Publications board world meteorological organization (WMO).Geneva: WMO. 